\title{
Hubungan Tingkat Stres dan Vulva Hygiene dengan Keputihan pada Remaja Putri
}

\author{
Febia Fitrie ${ }^{1}$, Aisyah Safitri ${ }^{2}$ \\ ${ }^{1,2}$ Program Studi Sarjana Keperawatan \\ Sekolah Tinggi Ilmu Kesehatan Indonesia Maju, Jakarta - Indonesia \\ Email: ${ }^{1}$ febiaf1497@gmail.com,2aisyirfan12@gmail.com
}

\begin{abstract}
Latar Belakang: Keputihan atau flour albus merupakan cairan bening yang keluar dari vagina dalam jumlah banyak. Terdapat dua macam keputihan yaitu keputihan normal (fisiologis) dan keputihan abnormal (patologis).

Tujuan: Tujuan peneliatin ini adalah untuk mengetahui hubungan stres dan vulva hygiene dengan keputihan pada remaja putri dikelas X (sepuluh) dan kelas XI (sebelas).

Metode: Desain penelitian ini menggunakan metode CrossSectional. Pengambilan sempel dilakukan secara stratified sampling. Sampel dalam penelitian ini adalah remaja putri kelas 10 dan 11 berjumlah 77 responden.

Hasil: Hasil penelitian untuk stres dengan keputihan menunjukan bahwa ada hubungan antara stres dengan keputihan (pvalue $=0,022$ ), hasil penelitian untuk vulva hygiene dengan keputihan menunjukan bahwa ada hubungan antara vulva dengan keputihan (p-value $=0,026, \mathrm{OR}=2,230)$.

Kesimpulan: Ada hubungan antara Stres Dan Vulva Hygiene Dengan Keputihan Pada Remaja Putri Dikelas 10 dan 11. Perlu diberikannya edukasi dan penyuluhan kepada siswi tentang cara mengatasi stres dan memberikan informasi pentingnya menjaga kebersihan vulva hygiene untuk menghindari terjadinya keputihan.
\end{abstract}

Kata Kunci: Stres, Vulva Hygiene, Keputihan.

Editor: WN

Hak Cipta:

(C2021 Artikel ini memiliki akses terbuka dan dapat didistribusikan berdasarkan ketentuan Lisensi Atribusi Creative Commons, yang memungkinkan peng-gunaan, distribusi, dan reproduksi yang tidak dibatasi dalam media apa pun, asalkan nama penulis dan sumber asli disertakan. Karya ini dilisensikan di bawah Lisensi Creative Commons Attribution-Share Alike 4.0 Interna-sional.

\section{Pendahuluan}

Berdasarkan data organisasi kesehatan dunia WHO (World Health Organization) tentang masalah kesehatan pada kaum hawa terutama pada sistem reproduksi telah mencapai 33\% dari total prevalensi penyakit yang diderita oleh perempuan. Di Indonesia sendiri berdasarkan data Badan Kependudukan dan Keluarga Berencana Nasional (BKKBN) tahun 2011 didapatkan perempuan yang mengalami keputihan adalah 75\% dari jumlah populasi dan $45 \%$ diantaranya mengalami lebih dari 
satu kali. ${ }^{1}$ Di Eropa, terdata sekitar 25\% wanita di wilayah tersebut pernah mengalami keputihan. Angka ini sangat berbeda tajam dengan yang terjadi di Indonesia, dimana persentase wanita Indonesia yang pernah mengalami keputihan tersebut cukup besar. Data penelitian di tahun 2010 hingga ke tahun 2013 menunjukkan angka keputihan pada wanita di Indonesia cenderung meningkat, dari 52\% menjadi $60 \%$ dan pada tahun 2013 pada trimester kedua didapatkan data 55\% wanita di Indonesia mengalami keputihan. Kasus ini dinilai menjadi masalah dalam reproduksi karena trennya yang semakin meningkat.

Di Indonesia wanita yang mengalami keputihan disebabkan karena keadaan cuaca di Indonesia yang lembab, berbeda dengan keadaan cuaca yang ada di eropa sehingga wanita di Eropa tidak mudah terinfeksi jamur yang menjadi penyebab keputihan (Hurlock, 2007). Salah satu penyebab terjadinya keputihan terutama pada remaja atau dewasa muda yaitu perilaku atau pola hidup yang tidak sehat, kurang aktivitas fisik dan tidak memperhatikan tentang diet, sehingga pada tahun 2008 berdasarkan data statsitik, remaja dengan usia 15-24 tahun didapatkan 43,3 juta tidak berperilaku sehat dan hal ini menjadi salah satu predisposisi terjadinya keputihan pada wanita atau remaja putri. ${ }^{2}$

Keputihan atau didalam dunia medis disebut flour albus. Keputihan yang sering terjadi pada sebagian perempuan dapat bersifat patologis maupun bersifat fisiologis (normal). Keputihan secara normal (terjadi secara fisiologis) biasanya sesuai dengan proses menstruasi. Gejala keputihan fisiologis diantaranya tidak tercium bau yang menyengat, jernih atau bening, tidak gatal, dan tidak perih. Keputihan apatologis terjadi karena adanya infeksi dari berbagai mikroorganisme, antara lain bakteri, jamur, dan parasit. Keputihan yang tidak normal ditandai dengan banyaknya jumlah cairan yang keluar dari vagina, berwarna putih seperti susu basi, kuning atau kehijauan, gatal, perih, dan disertai bau amis atau busuk. Warna pengeluaran dari vagina akan berbeda sesuai dengan penyebab dari keputihan. ${ }^{3}$ Keputihan sangat berisiko terjadi pada usia remaja sehingga sudah seharusnya remaja memperhatikan dan memiliki pengetahuan pada bidang ini, apalagi pada remaja putri yang baru memasuki periode pubertas, dimana pada saat itu terjadi menstruasi atau awal terjadinya haid. Pada sebagian wanita yang mengalami menstruasi dapat terjadi keputihan. Keputihan fisiologi dan patologi bisa juga disebabkan karena kurangnya menjaga vulva hygiene. ${ }^{4}$

Vulva hygiene atau dikenal dengan kebersihan vagina merupakan suatu tindakan yang dilakukan setiap hari untuk menjaga dan membersihakan organ kewanitaan bagian eksterna atau bagian luar vagina yang berguna untuk menghindari terjadinya infeksi serta penyakit-penyakit reproduksi lainnya. ${ }^{5}$

Pada remaja, keputihan dapat terjadi karena kurangnya menjaga kebersihan vulva, selain itu dapat disebabkan karena masalah psikis diantaranya adalah stres. Dampak kondisi tubuh yang lelah dan stress baik secara fisik maupun psikologi dapat menganggu kerja sel dan hormon-hormon yang ada dalam tubuh, salah satunya dapat meningkatkan sekresi hormon esterogen. Pengaruh hormon ini menyebabkan terjadinya keputihan pada wanita. ${ }^{2}$

Stress merupakan suatu keadaan ketika seseoarang merasakan beban yang tidak sebanding dengan kemampuan untuk mengatasi beban tersebut. ${ }^{6}$ Penelitian yang dilakukan oleh Hendiana Astusi, Joko Wiyono, dan Erkisa Candrawati (2018) yang meneliti tentang hubungan vaginal terjadinya keputihan pada mahasiswi yang ada di asrama putri PSIK UNITRI Malang, dalam penelitian tersebut, hasil yang didapatkan bahwa ada hubungan antara vaginal hygiene dengan keputihan pada mahasiswi asrama putri PSIK UNITRI. 
Berdasarkan hasil studi pendauhuluan yang dilakukan pada September 2018 di SMK Kesehatan Logos Bogor. Dari hasil wawancara dengan 11 siswa didapatkan 11 orang pernah mengalami stres, 7 orang stres saat kenaikan kelas, 4 orang stres saat UTS dan UAS, 6 orang dengan cara tidur ahu cara menghilangkan stres, 3 orang tidak tahu cara menenagkan stres, 2 orang dengan bermain menghilangkan stres, 9 orang mengatakan saat mendaptakan nilai buruk mereka merasakan stres. Dari 11 siswa 10 didapatkan tidak tahu cara membersihkan vagina dengan benar, 6 orang masih membersihkan vagina menggunakan sabun mandi, 8 orang mengganti celana dalam dua kali sehari, 10 orang mengganti pembalut 3 kali sehari. Dari 11 siswa didapatkan 10 orang tidak bisa membedakan keputihan normal dan tidak normal, 5 orang keputihan sebelum dan sesudah menstruasi, 2 orang pernah mengeluarkan cairan keputihan seperti putih susu bergumpal, 6 orang keputihan disertai gatal, 6 orang mengganti celana dalam saat keputihan dua kali sehari.

\section{Metode}

Metode yang peneliti gunakan dalam penelitian ini adalah jenis desain korelasi dengan pendekatan Cross Sectional. Data dikumpulkan pada waktu yang bersamaan (sekali waktu) antara faktor risiko/paparan dengan penyakit. Populasi dalam penelitian ini yaitu seluruh siswi kelas $\mathrm{X}$ dan XII di SMK Kesehatan Logos Bogor, Jawa Barat yang berjumlah 233 siswi. Populasi dalam sebuah penelitian merupakan wilayah generalisasi yang terdiri atas: objek/subjek yang mempunyai kuantitas dan karakteristik tertentu. ${ }^{12}$ Adapun sampel yang digunakan menggunakan teknik pengambilan sampel berdasarkan rumus Slovin maka sesuai dengan perhitunga, sampel yang diteliti berjumlah 77 orang, diharapakan sampel ini dapat mewakili jumlah populasi secara keseluruhan, yang juga mewakili karakteristik dari populasi tersebut. ${ }^{12}$

Teknik pemilihan sampel yang digunakan pada penelitian ini dengan cara teknik probability sampling stratified sampling, yaitu dengan cara penarikan sampel untuk populasi yang memiliki karakteristik heterogen atau karakteristik yang dimiliki populasi bervariasi. ${ }^{15}$ Instrumen yang digunakan dalam penelitian ini adalah kuesioner Percieved Stress Scale (PSS) sebanyak 10 pertanyaan untuk mengukur tingkat stres, vulva hygiene sebanyak 11 pertanyaan untuk mengetahui kebiasaan vulva hygiene, dan keputihan sebanyak 9 pertanyaan untuk mengetahui kejadian keputihan. Proses analisa data dalam penelitian ini dibagi menjadi 2 yaitu analisa Univariat yang bertujuan untuk menjelaskan karakteristik setiap variabel penelitian dan Analisa Bivariat bertujuan untuk menjelaskan hipotesis hubungan variabel tingkat depresi dengan variabel kualitas hidup. Uji Chi Square dilakukan untuk mengetahui antara dua variabel yaitu variabel independen dan dependen terdapat hubungan atau tidak dengan ketentuan nilai $\mathrm{p}$ value $<0.05$.

Hasil

Tabel 1. Distribusi frekuensi tingkat stres pada remaja putri di kelas 10 dan 11 SMK Kesehatan Logos Bogos-Jawa Barat Tahun 2018 ( $\mathrm{n}=77$ )

\begin{tabular}{ccc}
\hline Stres & Jumlah & Persentase (\%) \\
\hline Stres Rendah & 23 & 28,8 \\
\hline Stres Sedang & 9 & 11,7 \\
\hline
\end{tabular}




\begin{tabular}{ccc}
\hline Stres Berat & 45 & 58,4 \\
\hline Total & 77 & 100,0 \\
\hline
\end{tabular}

Berdasarkan tabel distribusi frekuensi menunjukkan distribusi frekuensi tingkat stres pada siswi kelas 10 dan 11 SMK Kesehatan Logos Bogor-Jawa Barat tahun 2018, sebagian besar mengalami stres berat sebanyak 45 orang (58\%).

Analisis distribusi frekuensi kebiasaan vulva hygiene responden dapat dilihat pada tabel berikut ini:

Tabel 2. Distribusi kebiasaan vulva hygiene pada remaja putri dikelas 10 dan 11 SMK Kesehatan Logos Bogor-Jawa Barat Tahun 2018 ( $\mathrm{n}=77)$

\begin{tabular}{ccc}
\hline Kebiasaan Vulva Hygiene & Jumlah & Persentase \\
\hline Baik & 36 & 46,8 \\
\hline Buruk & 41 & 53,2 \\
\hline Total & 77 & 100,0 \\
\hline
\end{tabular}

Berdasarkan tabel distribusi frekuensi menunjukkan distribusi frekuensi kebiasaan vulva hygiene pada siswi kelas 10 dan 11 SMK Kesehatan Logos Bogor-Jawa Barat tahun 2018, sebagian besar memiliki kebiasaan yang buruk sebanyak 41 orang $(53,2 \%)$.

Analisis distribusi frekuensi kejadian keputihan responden dapat dilihat pada tabel berikut ini:

Tabel 3. Distribusi kejadian keputihan pada remaja putri dikelas 10 dan 11 SMK Kesehatan Logos Bogor-Jawa Barat Tahun $2018(\mathrm{n}=77)$

\begin{tabular}{ccc}
\hline Kejadian Keputihan & Jumlah & Persentase \\
\hline Keputihan & 45 & 58,4 \\
\hline Tidak Keputihan & 32 & 41,6 \\
\hline Total & 77 & 100,0 \\
\hline
\end{tabular}

Berdasarkan tabel distribusi frekuensi menunjukkan distribusi frekuensi kejadian keputihan pada siswi kelas 10 dan 11 SMK Kesehatan Logos Bogor-Jawa Barat tahun 2018, sebagian besar mengalami keputihan sebanyak 45 orang $(58,4 \%)$.

Tabel 4. Hubungan Stres Dengan Keputihan Pada Remaja Putri Dikelas 10 dan 11 SMK Kesehatan Logos Bogor-Jawa Barat Tahun $2018(\mathrm{n}=77)$

\begin{tabular}{cccccc}
\hline \multirow{2}{*}{ Stres } & \multicolumn{2}{c}{ Keputihan } & Total & P-value \\
\cline { 2 - 6 } & \multirow{2}{*}{ Keputihan } & Tidak Keputihan & Jumlah & $\mathbf{\%}$ & 0,022 \\
\hline
\end{tabular}




\begin{tabular}{ccccccc}
\hline & F & $\mathbf{\%}$ & $\mathbf{F}$ & $\mathbf{\%}$ & & \\
\hline Stres Rendah & 10 & 55,6 & 8 & 44,4 & 18 & 100 \\
\hline Stres Sedang & 7 & 50,0 & 7 & 50,0 & 14 & 100 \\
\hline Stres Berat & 28 & 62,2 & 17 & 37,8 & 45 & 100 \\
\hline Total & 45 & 58,4 & 32 & 41,6 & 77 & 100 \\
\hline
\end{tabular}

Berdasarkan hasil tabel hubungan stres dan keputihan pada remaja putri kelas 10 dan 11 di SMK Kesehatan Logos Bogor menunjukan bahwa sebagian responden mengalami stres rendah 10 orang $(55,6 \%)$ untuk keputihan dan yang tidak keputihan 8 orang $(44,4 \%)$, stres sedang 7 orang $(50 \%)$ yang keputihan dan yang tidak keputihan 7 orang $(50 \%)$, dan stres berat sebesar 28 orang $(62,2 \%)$ untuk keputihan dan yang tidak keputihan 17 orang $(37,8 \%)$ dari total 77 responden. Hasil statistik diperoleh p-value 0,022 artinya ( $\mathrm{p}$-value $<\alpha=0,05$ ), maka dapat disimpulkan ada hubungan stres dengan keputihan pada remaja putri kelas 10 dan 11 SMK Kesehatan Logos Tahun 2018.

Tabel 5. Hubungan vulva hygiene dengan keputihan pada remaja putri kelas 10 dan 11 SMK Kesehatan Logos Bogor-Jawa Barat tahun 2018 (n=77)

\begin{tabular}{|c|c|c|c|c|c|c|c|c|}
\hline \multirow{3}{*}{$\begin{array}{l}\text { Vulva } \\
\text { hygiene }\end{array}$} & \multicolumn{4}{|c|}{ Keputihan } & \multicolumn{2}{|c|}{ Total } & \multirow[t]{3}{*}{ P-value } & \multirow[t]{3}{*}{ OR $(95 \%$ CI $)$} \\
\hline & \multicolumn{2}{|c|}{ Keputihan } & \multicolumn{2}{|c|}{$\begin{array}{c}\text { Tidak } \\
\text { Keputihan }\end{array}$} & \multirow[t]{2}{*}{ Jumlah } & \multirow[t]{2}{*}{$\%$} & & \\
\hline & $\mathbf{F}$ & $\%$ & $\mathbf{F}$ & $\%$ & & & & \\
\hline Baik & 22 & 61,1 & 14 & 38,9 & 36 & 100 & \multirow[t]{3}{*}{0,036} & \multirow{3}{*}{2,230} \\
\hline $\begin{array}{c}\text { Kurang } \\
\text { baik }\end{array}$ & 23 & 56,1 & 18 & 43,9 & 41 & 100 & & \\
\hline Total & 45 & 58,4 & 32 & 41,6 & 77 & 100 & & \\
\hline
\end{tabular}

Berdasarkan hasil tabel hubungan vulva hygiene dengan keputihan pada remaja putri kelas 10 dan 11 di SMK Kesehatan Logos Bogor mrnunjukan bahwa sebagian responden yang mengalami keputihan mempunyai kebiasaan vulva hygiene yang buruk 23 orang $(56,1)$ untuk yang tidak keputihan 18 orang $(43,9 \%)$, dan yang mempunyai kebiasaan vulva hygiene yang baik yang mengalami keputihan 22 orang $(61,1 \%)$ untuk yang tidak keputihan 14 orang $(38,9 \%)$ dari 77 responden.

Hasil statistik diperoleh p-value 0,036 artinya ( $\mathrm{p}$-value $<\alpha=0,05$ ), maka dapat disimpulkan ada hubungan stres dengan keputihan pada remaja putri kelas 10 dan 11 SMK Kesehatan Logos Tahun 2018. Dari hasil uji statistik diperoleh nilai OR (Odds Ratio) 2,230 yang artinya remaja yang mempunyai kebiasaan buruk dalam melakukan vagina hygiene 2,230 kali mengalami keputihan dibandingkan remaja yang mempunyai kebiasaan baik dalam melakukan vulva hygiene.

\section{Pembahasan}

Berdasarkan hasil penelitian yang dilakukan terhadap 77 remaja putri kelas 10 dan 11 di SMK Kesehatan Logos Bogor Jawa Barat mengalami stres sebagian besar mengalami stres berat sebanyak 45 orang (58\%), stres rendah sebanyak 23 orang $(28,8 \%)$, stres sedang sebanyak 9 orang $(11,7 \%)$. Hasil penelitian ini juga didukung oleh Kevin, Damajanty, dan Joice Hasil uji korelasi Spearman antara stres dan pola siklus menstruasi mendapatkan nilai $r=0,417$ dengan $\mathrm{p}=0,014$ yang menunjukkan terdapat hubungan moderat yang bermakna antara stres dan pola siklus menstruasi. Stres merupakan 


\section{J INDONESIA JOURNAL \\ of Miduifery sciences}

keadaan tegang secara biopsikososial karena banyaknya tugas-tugas yang harus dihadapi dalam kehidupan sehari-hari, baik dalam teman, keluarga, sekolah, maupun pekerjaan. ${ }^{14}$

Menurut penulis tentang hasil penelitian ini menunjukan bahwa remaja lebih mudah mengalami stres karena banyak tuntutan-tuntutan akademi seperti tugas sekolah, mudah marah jika mendapatkan niai buruk, banyaknya tugas yang menumpuk dan merasakan beban yang tidak sebanding dengan kemampuannya. Stres juga dapat diakibatkan dari tekanan kehidupan sehari-hari dan tekanan dari keluarga.

\section{Gambaran Kebiasaan Vulva Hygiene}

Hasil penelitian yang dilakukan pada remaja putri dikelas 10 dan 11 SMK Kesehatan Logos Bogos Jawa Barat didapatkan hasil bahwa sebagian siswi memiliki kebiasaan vulva hgiene yang buruk sebanyak 41 orang $(53,2 \%)$, dan kebiasaan yang baik sebanyak 36 orang $(46,8 \%)$. Hasil penelitian ini juga didukung oleh Fitriyya, Muslimah, Dan Alifia (2015) diketahui bahwa pengetahuan responden tentang tindakan vulva hygiene saat menstruasi baik 22 responden (34,9\%), cukup 34 responden (54 $\%)$ dan kurang 7 responden $(11,1 \%)$.

Kebersihan vagina atau biasa disebut dengan istilah Vulva Hygiene merupakan suatu kebiasaan rutin untuk memelihara dan menjaga kebersihan organ vagina bagian luar (eksternal) yang dilakukan untuk menjaga kesehatan dan mencegah terjadinya infeksi seperti tindakan membasuh kemaluan dari arah depan ke belakang menggunakan air yang besih dan mengalir, tidak membersihkan menggunakana sabun mandi, mengeringkannya dengan handuk kering dan bersih, mencuci tangan sebelum membersihkan vagina. ${ }^{13}$

Tujuan melakukan vulva hygiene yaitu untuk menjaga kebersihan vagina agar tetap bersih, sehat, tidak lembab dan supaya bakteri tidak mudah masuk kedalam vagina yang mengakibatkan bau tidak sedap, terasa gatal, dan menimbulkan keputihan yang berlebihan. ${ }^{7}$

Menurut penulis tentang hasil penelitian ini menunjukan bahwa sebagian besar remaja yang mengalami keputihan disebabkan karena masih kurang baik dalam menjaga kebersihan vagina seperti tidak tahu cara membersihkan vagina dengan baik dan benar, masih menggunakan sabun mandi untuk membersihkan vagina, dan tidak mengganti celana dalam 3 kali sehari

\section{Keputihan}

Hasil penelitian yang dilakukan pada remaja putri dikelas 10 dan 11 SMK Kesehatan Logos Bogos Jawa Barat didapatkan hasil yang mengalami keputihan sebanyak 45 orang ( $58,4 \%$ ), dan yang tidak keputihan sebanyak 32 orang $(41,6 \%)$. Hasil penelitian ini juga didukung dari hasil penelitian yang dilakukan oleh Susanti dan Wijaya (2018) diketahui bahwa kejadian keputihan pada mahasiswa Prodi D III Kebidanan sejumlah 33 ( 82.8\%) mengalami keputihan flsiologis, 1 (2.6\%) mengalami keputihan patologis dan 4 ( 10.5\%) tidak keputihan.

Pada wanita merupakan salah satu masalah kesehatan reproduksi yang sering terjadi pada wanita terutama pada usia remaja. Keputihan adalah keluarnya cairan bening selain darah dari liang vagina baik berbau maupun tidak berbau dan tidak disertai rasa gatal didaerah kewanitaan. ${ }^{8}$ Keputihan yang terjadi pada wanita bisa menjadi serius jika tidak ditangani dengan baik dan bisa menyebabkan terjadinya kanker serviks. Untuk menghindari penyakit tersebut wanita harusnya memperhatikan dan menjaga kebersihan alat reproduksinya dan melakukan kebiasaan vulva hygiene yang baik. Melalui tindakan vulva hygiene yang baik, dapat mengurangi resiko terjadinya keputihan. ${ }^{2}$ 
Menurut penulis tentang hasil penelitian ini menunjukan bahwa sebagian remaja yang mengalami keputihan diakibatkan bakteri yang yang disebabkan kurangnya menjaga kebersihan vagina sehingga mengalami keputihan, keputihan yang dialami bisa menjadi salah satu penyebab timbulnya penyakit lain jika tidak segera dirubah kebiasaan sehari-hari terutama dalam membersihkan serta menjaga kesehatan vagina.

\section{Hubungan Stres dengan Keputihan}

Berdasarkan hasil yang didapat, menunjukan bahwa setelah dilakukan uji chi square didapatkan $p$-value,022 artinya ( $\mathrm{p}$-value $<\alpha=0,05$ ), maka dapat disimpulkan ada hubungan stres dengan keputihan pada remaja putri kelas 10 dan 11 SMK Kesehatan Logos Tahun 2018.

Hal ini sesuai dengan hasil penelitian oleh Wulandari, Hadiati, dan Widodo (2017) bahwa terdapat korelasi yang bermakna antara tingkat stres terhadap tingkat insomnia pada responden dengan arah hubungannya positif sedang ditandai dengan nilai signifikan $\mathrm{p}<0,001$ dan $\mathrm{r}=0,520$, karena nilai $\mathrm{p}<0,05$ dan nilai $\mathrm{r}$ positif dan terletak antara $0,4-0,599$. Stres merupakan masalah yang terjadi yang dialami setiap individu didalam kehidupannya sehari-hari. Dalam filosofi negara bagian timur, dikatakan stres apabila tidak adanya rasa tenang didalam batin, sedangkan dalam budaya barat, stress merupakan sebagai kehilangan kontrol emosi. ${ }^{9}$

Menurut penulis hasil dari penelitian hubungan stres dengan keputihan ini bahwa adanya hubungan antara stres dengan keputihan. Keputihan yang terjadi bisa disebabkan karena masalah psikis diantaranya adalah stres kondisi tubuh yang lelah dan stres dapat memicu peningkatan hormon estrogen yang menyebabkan terjadinya keputihan.

\section{Hubungan Vulva Hygiene dengan Keputihan}

Berdasarkan hasil yang didapat, menunjukan bahwa setelah dilakukan uji chi square didapatkan -value 0,036 artinya (p-value $<\alpha=0,05$ ), maka dapat disimpulkan ada hubungan stres dengan keputihan pada remaja putri kelas 10 dan 11 SMK Kesehatan Logos Tahun 2018. Dari hasil uji statistik diperoleh nilai OR (Odds Ratio) 2,230 yang artinya remaja yang mempunyai kebiasaan buruk dalam melakukan vagina hygiene 2,230 kali mengalami keputihan dibandingkan remaja yang mempunyai kebiasaan baik dalam melakukan vulva hygiene.

Hal ini sesuai dengan hasil penelitian oleh Muthoharoh dan Widiyawati diketahui sebagian besar perilaku vulva hygiene saat menstruasi dengan menggunakan uji t test nilai sig. $0,016<\alpha 0,05$ ada pengaruh pendidikan kesehatan terhadap perilaku vulva hygiene saat menstruasi.

Kebersihan organ reproduksi pada wanita adalah dengan vulva hygiene yang merupakan suatu tindakan untuk memelihara kebersihan dan kesehatan organ reproduksi untuk kesejahteraan secara fisik dan psikis. ${ }^{10}$ Adapun langkah atau tata cara melakukan Vulva Hygiene atau pembersihan daerah genetalia, maka dapat dilakukan sebagai berikut: mencuci tangan sebelum membersihkan vagina, satu hal yang harus diperhatikan dalam membasuh daerah kewanitaan membersihkan dengan air bersih dan mengalir, setelah buang air besar (BAB), dibersihkan dengan cara membasuh dari arah depan kebelakang (dari vagina kearah anus), bukan sebaliknya. Karena apabila terbalik arah membasuhnya, maka kuman dari daerah anus akan terbawa kedepan dan dapat masuk kedalam vagina, apabila membersihkan daerah kewanitaan menggunakan sabun, sebaiknya dibagian luarnya saja, seperti daerah labiya mayora dan labiya minora, selalu mengeringkan vagina selesai membersihkannya agar vagina tidak lembab. ${ }^{11}$ 
Menurut penulis hasil dari penelitian hubungan vulva hygiene dengan keputihan ini bahwa adanya hubungan antara stres dengan keputihan. Keputihan bisa terjadi akibat dari kurangnya menjaga kebersihan vagina terutama dalam praktik membersihkan vagina seperti tidak mencuci tangan terlebih dulu, tidak memerhatikan kebersihan air. Kebiasaan membersihkan vagina yang buruk dapat dengan mudah bakteri yang masuk ke vagina sehingga menyebabkan keputihan.

\section{Kesimpulan}

Hasil penelitian menunjukkan bahwa sebagian besar remaja putri disekolah tersebut mengalami stres berat dan mempuyai kebiasaan vulva hygiene yang buruk. Hasil penelitian ini juga memperlihatkan bahwa ada hubungan antara stres dan vulva hygiene dengan keputihan pada remaja putri. Hal ini disebabkan karena kurangnya pengetahuan siswi mengenai kebersihan vagina dengan melakukan teknik vulva hygiene yang baik dan benar, seperti tidak mencuci tangan terlebih dahulu sebelum membersihkan vagina dan jarang membersihkan vagina dalam sehari.

Diharapkan penelitian ini bagi sekolah memberikan materi tentang stres dan vulva hygiene dan sebagai ragam informasi mengenai hubungan stres dan vulva hygiene dengan keputihan pada remaja putri di SMK Kesehatan Logos Bogor-Jawa Barat.

Dan untuk peneliti selanjutnya Sebagai referensi untuk penelitian selanjutnya yang berkaitan dengan stres dan vulva hygiene dengan keputihan dan penelitian selanjutnya dapat melakukan penelitian mengenai faktor yang paling berhubungan antara stres dan vulva hygiene dengan keputihan.

\section{Konflik Kepentingan}

Penelitian ini tidak ada konflik kepentingan apapun baik secara individu maupun organisasi

\section{Ucapan Terima Kasih}

Terimakasih kepada semua responden yang telah berkontribusi pada penelitian ini

\section{Pendanaan}

Sumber pendanaan pada penelitian ini adalah individu.

\section{References}

1. Abrori, A. D. Faktor yang berhubungan dengan kejadian keputihan patologis siswi SMAN 1 Simpang Hilir Kabupaten Kayong Utara. Unnes Journal of public health.2017

2. Muhammad Darma, S. Y. Hubungan pengetahuan, vulva hygiene, stres, dan pola makan dengan kejadian infeksi flour albus (keputihan) pada remaja siswi SMA Negri 6 kendari 2017. Jurnal Ilmiah Mahasiswa Kesehatan Masyarakat.2017

3. Marhaeni, G. A. Keputihan pada wanita. Jurnal skala Husada Volume 13 no 1. 2016

4. Werdiani. Karakteristik remaja putri dengan kejadian keputihan di SMK Muhammadiyah Kudus. JIKK Vol. 6 no. 1.2012

5. Sriani Timbawa, R. K. Hubungan vulva hygiene dengan pencegahan infeksi luka perineum pada ibu post partum dirumah sakit pancaran kasih manado. E-journal keperawatan, vol.3. 2015

6. Musradinur. Stres dan cara mengatasinya dalam perspektif psikologi. Jurnal edukasi vol.2. 2016

7. Putri sekar. Pengaruh pendidikan kesehatan tentang vulva hygiene terhadap pengetahuan, sikap dan praktik remaja putri yang mengalami keputihan dipondok pesantren al-izzah demak. 2016

8. Asikin M, Nuralamsyah M. Susaldi.(2016). Keperawatan Medikal Bedah Sistem Kardiovaskular.

9. Kuntoro. Pengetahuan personal hygiene remaja putri pada kasus keputihan. Jurnal biometrika dan kependudukan, volume no 1 .

10. Ariyanto. Tingkat stres pada remaja dilapas blitar. Jurnal psikolog indonesia. 2016 


\section{J INDONESIA JOURNAL M S OF Miduifery sciences}

11. Adila Noor Rifa. Perbedaan tingkat pengetahuan remaja putri tentang vulva hygiene. 2012

12. Wijaya. Hubungan penggunaan pembalut dan pantyliner jenis herbal atau biasa. Jurnal kebidanan, vol.2. 2018.

13. Sugiyono, Metode Penelitian Pendidikan Kuantitatif, Kualitatif, Dan R \& D. Bandung: Alfabeta 2010

14. Yani Widyastuti, A. R. Kesehatan Reproduksi. Yogyakarta: Penerbit Fitramaya. 2009

15. Rizka Adela Fatsena, S. N. Hubungan Tingkat stres dengan siklus menstruasi Pada Siswi Kelas XII SMA Negeri 3 Sukoharjo. 2017

16. Suharsimi Arikunto, manajemen Penelitian. Jakarta: Rineka Cipta. 2010. 